\title{
Hydrogeology of Glacial Drift, Mesabi Iron Range, Northeastern Minnesota
}

GEOLOGICAL SURVEY WATER-SUPPLY PAPER 2029-A

Prepared in cooperation with the Minnesota Department of Iron Range Resources and Rehabilitation

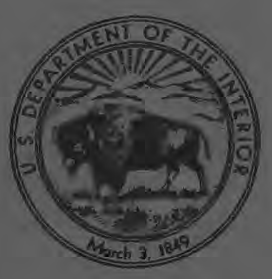




\section{Hydrogeology of Glacial Drift, Mesabi Iron Range, Northeastern Minnesota}

BY THOMAS C. WINTER

CONTRIBUTIONS TO THE HYDROLOGY OF THE UNITED STATES

GEOLOGICAL SURVEY WATER-SUPPLY PAPER 2029-A

Prepared in cooperation with the Minnesota Department of Iron Range Resources and Rehabilitation

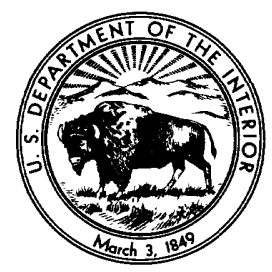




\section{UNITED STATES DEPARTMENT OF THE INTERIOR}

ROGERS C. B. MORTON, Secretary

\section{GEOLOGICAL SURVEY}

v. E. McKelvey, Director

Library of Congress catalog-card No. $72-600356$

For sale by the Superintendent of Documents, U.S. Government Printing Office Washington, D.C. 20402 - Price $\$ 2.10 \quad$ Stock Number 2401-02419 


\section{CONTENTS}

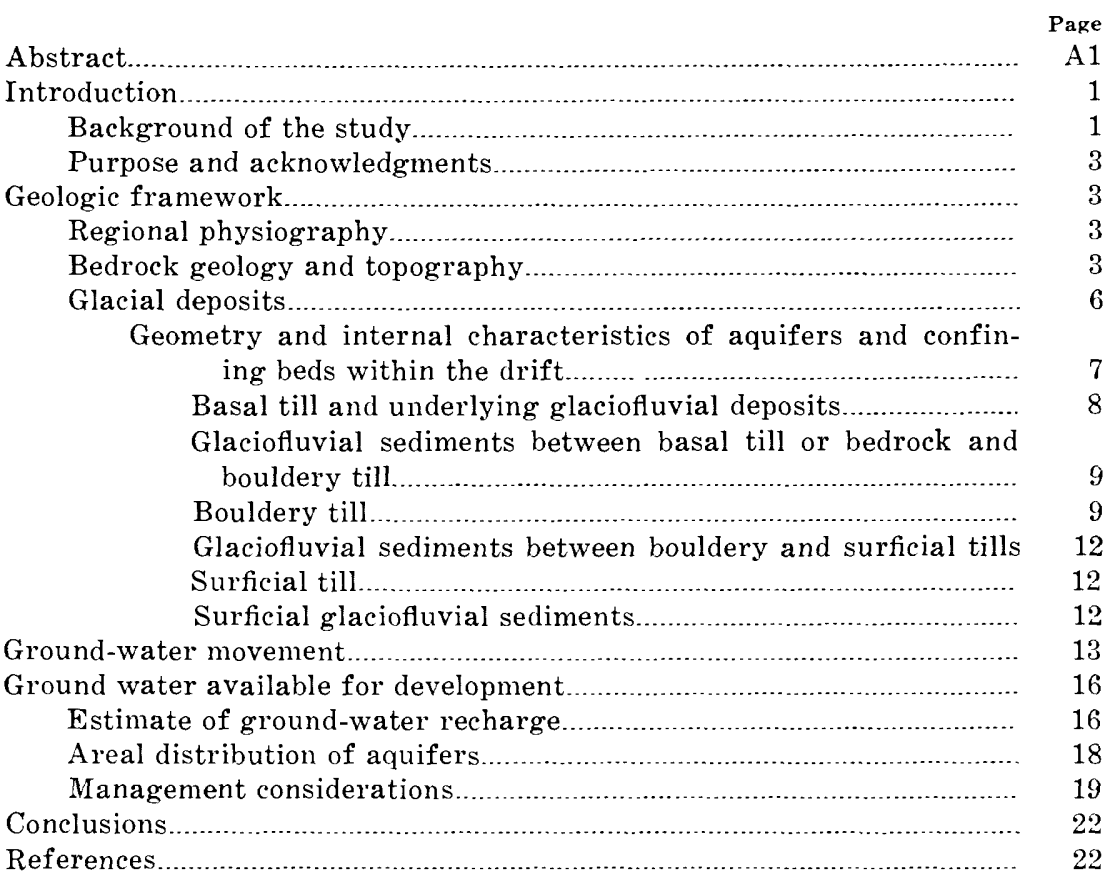

\section{ILLUSTRATIONS}

[Plates are in pocket]

Plate 1. Maps showing bedrock geology and thickness of glacial drift, Mesabi Iron Range, northeastern Minnesota.

2. Geohydrologic maps of the basal till and glaciofluvial sediments between basal till or bedrock and bouldery till, Mesabi Iron Range, northeastern Minnesota.

3. Geohydrologic maps of glaciofluvial sedinents between bouldery and surficial tills, Mesabi Iron Range, northeastern Minnesota.

Figures 1-5. Maps showing:

Page

1. Location of report area.

2. Topography, precipitation, and surface-water drainage

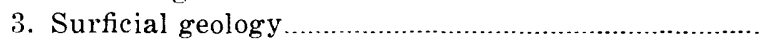


Figures 1-5-Continued Page

4. Thickness of surficial glaciofluvial sediments.......... A14

5. Transmissivity of surficial glaciofluvial sediments 15

6. Sections showing stratigraphy of aquifers and confining beds in three areas of high potential for ground-water development.

\section{TABLE}

TABLE 1. Values of hydraulic conductivity used to estimate transmissivity 


\title{
CONTRIBUTIONS TO THE HYDROLOGY OF THE \\ UNITED STATES
}

\section{HYDROGEOLOGY OF GLACIAL DRIFT, MESABI IRON RANGE, NORTHEASTERN MINNESOTA}

\author{
By Thomas C. Winter
}

\section{ABSTRACT}

Stratified fluvial sediments occur within the glacial drift at many places in the Mesabi Iron Range area. These sediments, which are important aquifers, occur extensively between the three main till units. The thickest and most extensive aquifer consists of glaciofluvial sediments that lie between the surficial till and the middle till unit, the bouldery till. Thickness of the glaciofluvial sediments at this stratigraphic interval is greater than 50 feet in much of the area, and transmissivity is greater than 100,000 gallons per day per foot in some places.

Glaciofluvial sediments underlying the bouldery till occur largely in the western half of the area. These sediments are generally less than 50 feet thick, and transmissivity is generally less than 50,000 gallons per day per foot.

Surficial glaciofluvial sediments are a source of ground water for highyield wells only in the eastern part of the area in the vicinity of the Biwabik bedrock valley. Thickness of these sediments is greater than 100 feet in some places, but transmissivity is generally less than 50,000 gallons per day per foot.

Practical sustained yield of aquifers in glacial drift is estimated to be as much as 40 million gallons per day from known aquifers. Assuming that the ratio of area underlain by aquifer to total area is constant for the study area (about 20 percent where mapped in detail), as much as 80 million gallons per day could be developed from glacial-drift aquifers.

\section{INTRODUCTION}

\section{BACKGROUND OF THE STUDY}

Demands for water are increasing rapidly in the Mesabi Iron Range area (fig. 1). Total water use in 1959 was about $370 \mathrm{mgd}$ (million gallons per day), of which about $20 \mathrm{mgd}$ was "consumed" (Cotter and others, 1965a). Since then taconite processing, which requires large quantities of water, has increased greatly. It is estimated that by the year 1980 consumptive use of water for 


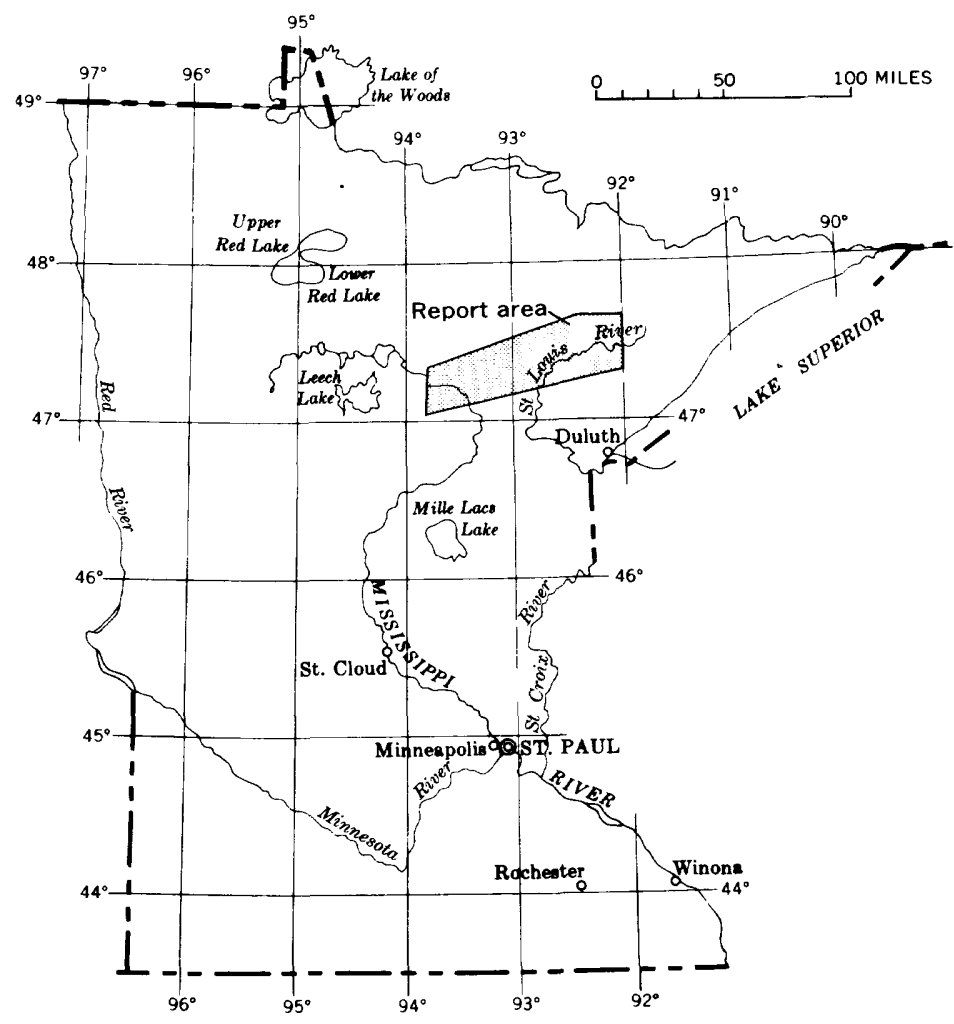

FiguRe 1. - Location of report area.

taconite processing alone will be about $78 \mathrm{mgd}$ (State Planning Agency, 1970), and total consumptive use for all purposes will be about $168 \mathrm{mgd}$ (Barr Engineering, 1969).

To satisfy future demands for water, conjunctive development of both ground- and surface-water resources will be necessary. Some municipalities and industries use ground water, but the largest water users have developed surface water for their source of supply. Future expansion of water development should consider the following: The area is largely a headwaters area (fig. 2), and the natural surface-water supply is limited; the terrain is not suitable for large reservoirs; and ground water is relatively undeveloped.

The Minnesota Department of Iron Range Resources and Rehabilitation and the U.S. Geological Survey, realizing the need for conjunctive resource development and hence for more information related to the ground-water resource, conducted a series of projects from the mid 1950's to 1962 to map and evaluate local ground-water resources. These projects and the reports that resulted from them concentrated largely on local areas, principally 
near municipalities. (See for example Cotter and others, 1965a, b, c, d, e, f; Maclay, 1966; Lindholm, 1968; and Oakes, 1970.) From 1968 to 1971 , the abundant local data were examined from a regional point of view. The report prepared on the regional stratigraphy of glacial drift (Winter and others, 1973) established the stratigraphic position of the principal drift aquifers and was prerequisite to the geologic mapping necessary for ground-water evaluation. This evaluation consists of delineating the overall geometry of the aquifers and confining beds and mapping the internal variations of grain size and sorting.

\section{PURPOSE AND ACKNOWLEDGMENTS}

The purpose of this report is twofold. The primary purpose is to delineate the principal glacial-drift aquifers and to describe their overall geometry and variations in grain size. The information is presented in a format which will facilitate preparation of the data for quantitative modeling. The secondary purpose is to describe ground-water movement in the Mesabi Iron Range and to make a preliminary approximation of the practical sustained yield that can be developed from the ground-water system to meet future water demands.

The cooperation of well owners, well drillers, municipalities, and mining companies in allowing free access to information and data is greatly appreciated.

\section{GEOLOGIC FRAMEWORK}

\section{REGIONAL PHYSIOGRAPHY}

The study area consists of about 1,400 square miles in St. Louis and Itasca Counties. It is bounded on the north by the Giants Range, a long linear ridge of granitic hills that stand 200-400 feet higher than the land immediately to the south (fig. 2). The rest of the area consists of landforms that resulted from glacial deposition more than 10,000 years ago (Winter, 1971). The surficial glacial deposits consist of red clayey till in the eastern part of the area and brown silty till in the western part (fig. 3). Overlying the surficial tills in much of the south-central and western parts of the area are fine sand, silt, and clay deposits of glaciallake origin (Cotter and others, 1964). Hummocky topography of morainal and ice-contact landforms that have local relief up to 50 feet are common in the areas of till (Winter and others, 1973). Topographic relief in the glacial-lake plains is only a few feet, and vast peatlands covering many square miles are common.

\section{BEDROCK GEOLOGY AND TOPOGRAPHY}

Granite, quartzite, iron-formation, argillite, and gabbro of Precambrian age underlie the study area (pl. 1A). Conglomerate, 


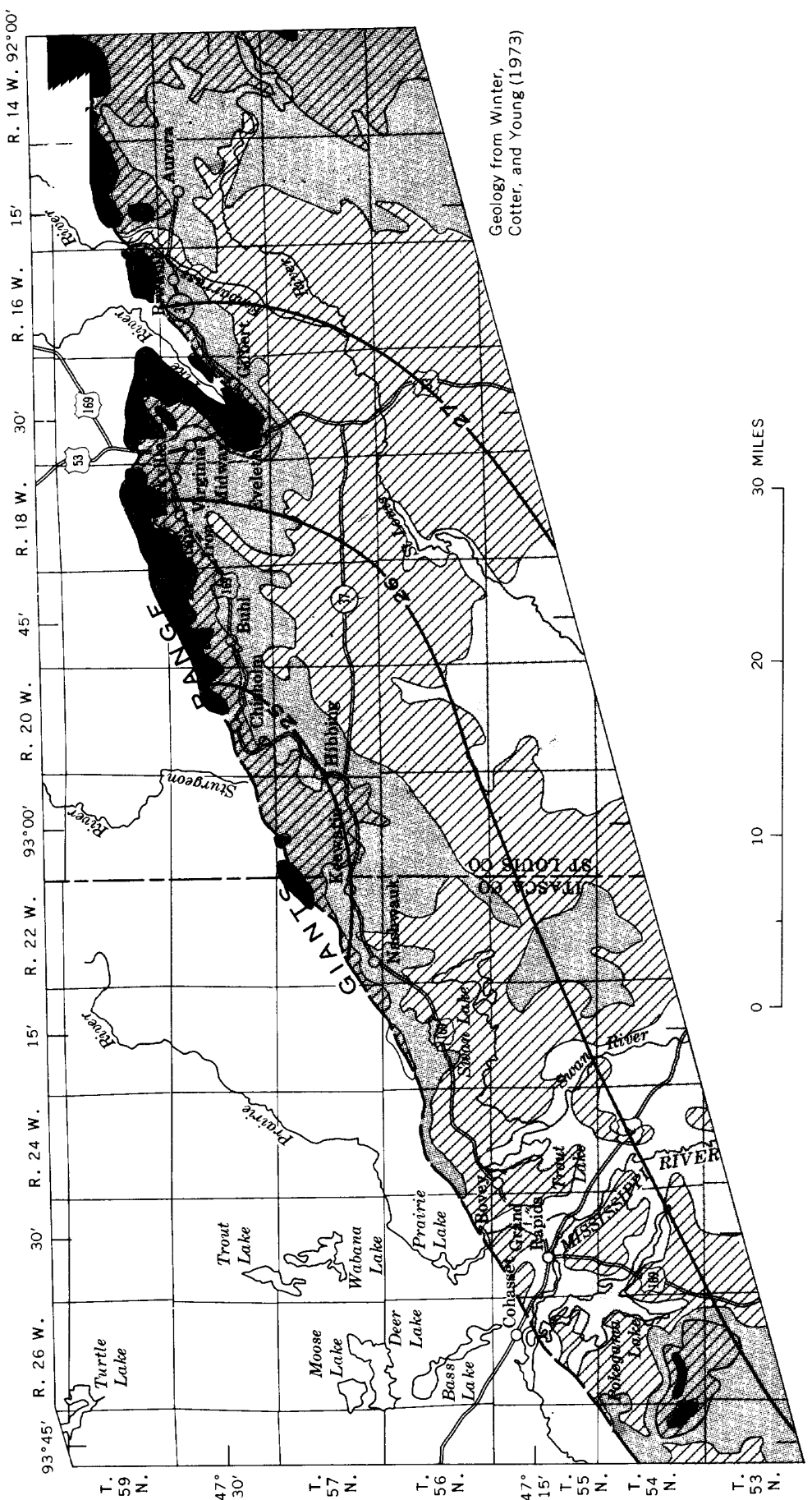




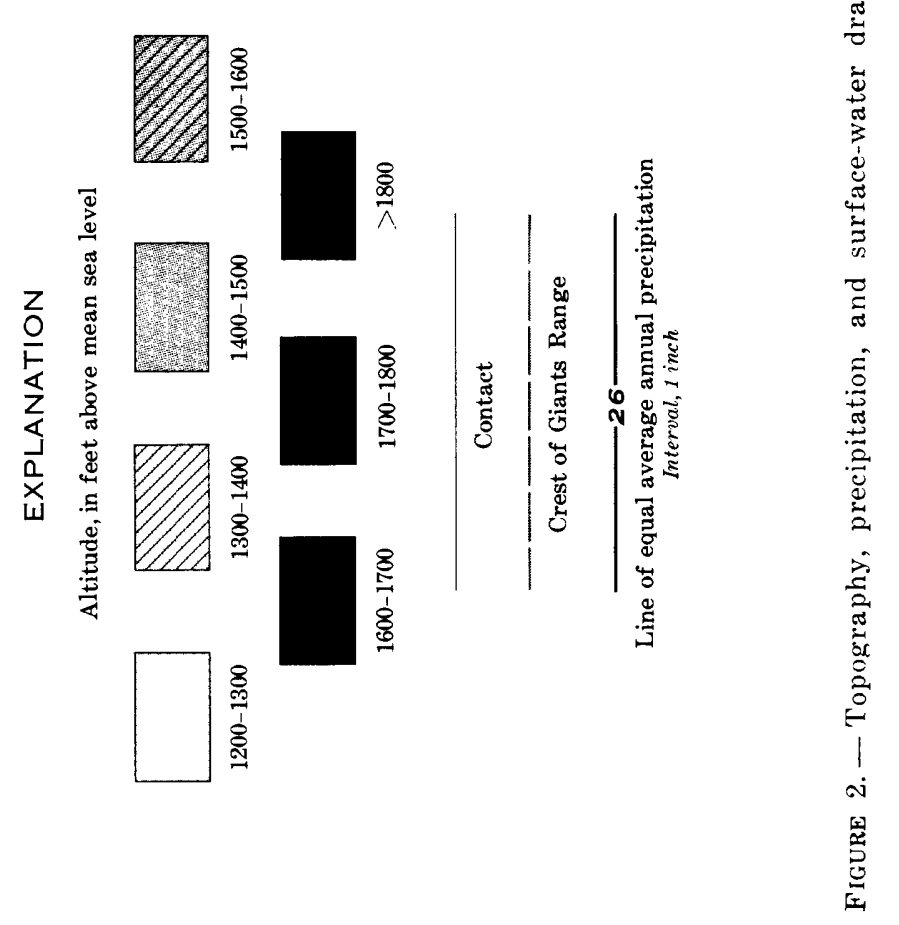


sandstones, and shales of Cretaceous age overlie the Precambrian rocks in the western half of the area. Thickness and extent of the Cretaceous rocks are not well known. Locally, drill holes have penetrated as much as 200 feet of Cretaceous material, but nearby holes report almost none. A map prepared by the Minnesota Geological Survey (1970) shows the eastern limit of Cretaceous rocks to be between Eveleth and Gilbert, which is considerably farther east than is shown on plate $1 A$. The difference is undoubtedly due to differing purposes for mapping. The map prepared by the Minnesota Geological Survey shows the extent of the Cretaceous deposits whether continuous or not, whereas plate $1 \mathrm{~A}$ shows the present extent of continuous Cretaceous deposits, which has greater hydrologic significance.

Four valleys occur on the bedrock surface (pl. $1 A$ ). Knowledge of the location and extent of these valleys is important because the thickness of the overlying surficial deposits is greatest in the bedrock-valley areas. Generally, the greater the thickness of deposits, the greater the volume of water present; therefore, the bedrock-valley areas may offer the highest potential for groundwater development.

The largest valley, referred to in this report as the Biwabik bedrock valley, is oriented northeast-southwest. It extends from south of Eveleth to the Embarrass Channel, a large gap in the Giants Range between Aurora and Biwabik. The valley is broad and is several hundred feet deep.

The second largest valley, informally referred to as the Hibbing bedrock valley, extends south from Hibbing. It is narrow and steep sided and has relief of 100-150 feet.

The third largest valley, referred to in this report as the Virginia bedrock valley, extends southwest from Virginia. It is broad and is less than 100 feet deep.

The fourth valley, informally referred to as the Swan Lake bedrock valley, is poorly defined. It directly underlies Swan Lake and is alined with the lake. Depth of the valley is probably less than 100 feet.

Other bedrock valleys probably exist in the Mesabi Iron Range area, particularly in the western part, but spacing of test holes has not been sufficiently close to define them.

\section{GLACIAL DEPOSITS}

Glacial drift in the Mesabi Iron Range area consists of three major till units and associated glaciofluvial deposits. The till units are informally referred to as the basal till, bouldery till, and surficial till. The basal till is stratigraphically the lowest. The bouldery till (the middle till unit) is the thickest and most continuous 
of the three. The surficial till is fairly extensive but is thin, generally less than 25 feet thick. Total thickness of all drift units ranges from zero along the base of the Giants Range to 250-300 feet in two bedrock valleys and southeast of Grand Rapids (pl. $1 B$ ). In most of the area the drift is greater than 100 feet thick.

GEOMETRY AND INTERNAL CHARACTERISTICS OF AQUIFERS AND CONFINING BEDS WITHIN THE DRIFT

Delineation of the extent and thickness of aquifers within the drift is essential to the evaluation of ground-water resources. This delineation is particularly difficult because glacial deposits are characteristically highly variable in thickness and areal extent, as is evident in nearly every mine exposure on the Mesabi Range. In general, however, the major sand and gravel deposits (aquifers) occur between till units (confining beds) or at the surface.

Internal characteristics of the glacial units such as grain size, porosity, and lithology are also highly variable. Illustrating this variation is particularly difficult because three-dimensional data must be shown on two-dimensional hydrogeologic maps.

In this report the variations in average grain size within the principal aquifers can be inferred from maps showing transmissivity and thickness. Transmissivity maps were constructed in the following way. Each drill log was examined, and hydraulic conductivity (permeability) values (as shown in table 1) were assigned according to grain size to each lithologic unit within an aquifer. Hydraulic conductivity of a medium is "the volume of water at the existing kinematic viscosity that will move in unit time under a unit hydraulic gradient through a unit area measured at right angles to the direction of flow" (Lohman and others, 1972). The hydraulic conductivity value was multiplied by the thickness of each lithologic unit within the aquifer; these values were added to obtain an overall transmissivity value for each aquifer in the drill $\log$. Since transmissivity can be related to thickness and average grain size, the grain-size variation can be determined. The hydrologic significance of the transmissivity maps is discussed later. Geologically, the method is believed to be acceptable providing consistency is assured. A single table of values must be used for all the units, and assignment of values should be done by, or supervised by, one person. The table of hydraulic conductivity values (table 1) is similar to those used by Van Voast (1971), Lindholm (1970), and Reeder (1972) in evaluating other drift aquifers in Minnesota.

Of the approximately 1,000 drill logs and measured mine sections on file, about 500 of the most complete and detailed were 
used to construct the maps for this report. In general, more information is available for the upper units than for the lower because many of the test holes did not penetrate the bouldery till. This can be readily seen by comparing the number of test holes on plates $2 B$ and 3 .

TABLE 1. - Values of hydraulic conductivity used to estimate transmissivity

\begin{tabular}{|c|c|}
\hline $\begin{array}{c}\text { Material } \\
\text { (based on Wentworth scale) }\end{array}$ & $\begin{array}{l}\text { dydraulic conductivity } \\
\text { (gallons per day } \\
\text { per square foot) }\end{array}$ \\
\hline Clay....... & 0.10 \\
\hline (. & $0.1-1.00$ \\
\hline Silt $\ldots \ldots \ldots \ldots \ldots \ldots \ldots \ldots$ & 1.00 \\
\hline Sand, very fine, silty. & $100-200$ \\
\hline 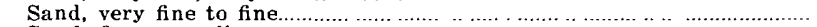 & $200-300$ \\
\hline 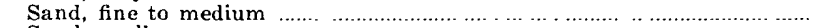 & $300-400$ \\
\hline 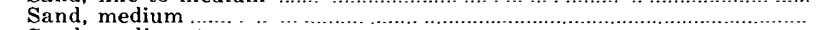 & $400-600$ \\
\hline Sand, medium to coarse & $600-800$ \\
\hline 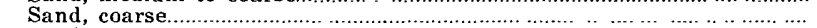 & $800-900$ \\
\hline 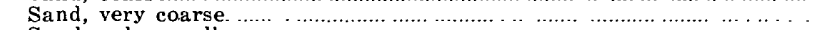 & $900-1,000$ \\
\hline 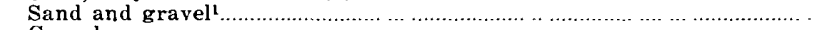 & $1,000-2,000$ \\
\hline 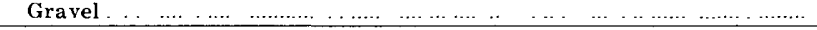 & $>5,000$ \\
\hline
\end{tabular}

${ }^{1} \mathrm{Hydraulic}$ conductivity values for sand-and-gravel size range:

\begin{tabular}{|c|c|c|c|c|c|}
\hline & & & G R A & VEL & \\
\hline & & Fine & Medium & Coarse & $\begin{array}{l}\text { Very } \\
\text { coarse }\end{array}$ \\
\hline a & Fine & 1,000 & 1,200 & 1,400 & 1,600 \\
\hline & Medium & 1,200 & 1,400 & 1,600 & 1,800 \\
\hline 4 & Coarse & 1,400 & 1,600 & 1,800 & 2,000 \\
\hline & Very coarse & 1,600 & 1,800 & 2,000 & $>2,000$ \\
\hline
\end{tabular}

BASAL TILL AND UNDERLYING GLACIOFLUVIAL DEPOSITS

The basal till is continuous eastward to the Hibbing area (pl. $2 A$ ). Its thickness is generally between 50 and 100 feet, but near Hibbing it is greater than 100 feet. East of Hibbing the basal till has been identified in only two test holes and in the Embarrass mine near Aurora, where the basal till is greater than 100 feet thick.

The basal till is dark gray to dark greenish and brownish gray. The till is unsorted; the dominant grain size is sand and gravel, but clay and silt are also abundant. The percentage of clay and silt is slightly greater in the central and western parts of the area than in the eastern part (Winter and others, 1973). Cobbles and some boulders are also scattered throughout the till. The till is calcareous and, as determined from a hot hydrochloric acid treatment of samples, contains between 5 and 15 percent soluble material.

Few data are available on glaciofluvial sediment underlying the basal till. At most places the till lies directly on bedrock. The only known occurrences of continuous stratified drift at this stratigraphic interval are near Hibbing and near Grand Rapids. Near Hibbing, the stratified drift ranges from 6 to 122 feet thick, but the bulk of this is clay and silt. The thickness of sand within 
the glaciofluvial section is generally not more than 30 feet, and this occurs in only a few test holes. Stratified drift underlying basal till near Grand Rapids is reported in only three test-hole $\operatorname{logs}$, one of which recorded 70 feet of sand.

Though data are sparse, indications are that glaciofluvial sediments underlying the basal till in the Mesabi Iron Range area are not extensive and that most of these sediments are clay and silt.

GLACIOFLUVIAL SEDIMENTS BETWEEN BASAL TILL OR BEDROCK AND BOULDERY TILL

Stratified glacial drift underlying the bouldery till is probably continuous in the western and central parts of the area (pl. $2 B$ ). It occurs also in small areas between Mountain Iron and Virginia and near Aurora. Generally, the glaciofluvial deposits at this stratigraphic interval are less than 50 feet thick. The only occurrences of stratified drift greater than 50 feet thick are at scattered localities in the western part of the area and near Hibbing, where it is greater than 100 feet thick.

The variation in grain size of the glaciofluvial deposits at this stratigraphic interval is fairly wide, but the deposits consist largely of sand or sand and gravel (pl. $2 B$ ). The deposits are relatively fine grained, however, directly south of Hibbing and in scattered localities near and southeast of Grand Rapids.

BOULDERY TILL

The bouldery till, deposited by glacial ice that moved into the area from the northeast across the Giants Range (Winter, 1971), is relatively continuous across the entire area. The till is absent in the general area of the Virginia bedrock valley and in scattered local areas throughout the Iron Range. Thickness of the till is generally less than 50 feet, and in much of the area it is less than 25 feet. At scattered localities the thickness exceeds 50 feet, and in a few test-hole logs and mine sections it is more than 75 feet.

The bouldery till is characterized by many cobbles and boulders in a sandy, silty matrix. It ranges from gray to yellow, red, orange, or brown. It consists of sand, silt, and abundant cobbles and boulders, and it is noncalcareous. The bouldery till contains generally less than 8 percent soluble material. Colored (yellow, red, orange, or brown) bouldery till below gray bouldery till may be a separate subunit, distinguished largely by particle size, but its overall characteristics are similar to those of the gray bouldery till. Lenses of stratified glaciofluvial deposits are common in the bouldery till. The grain size and degree of sorting of this included stratified drift is highly variable, but most lenses are local and consist of fine sand and silt. 


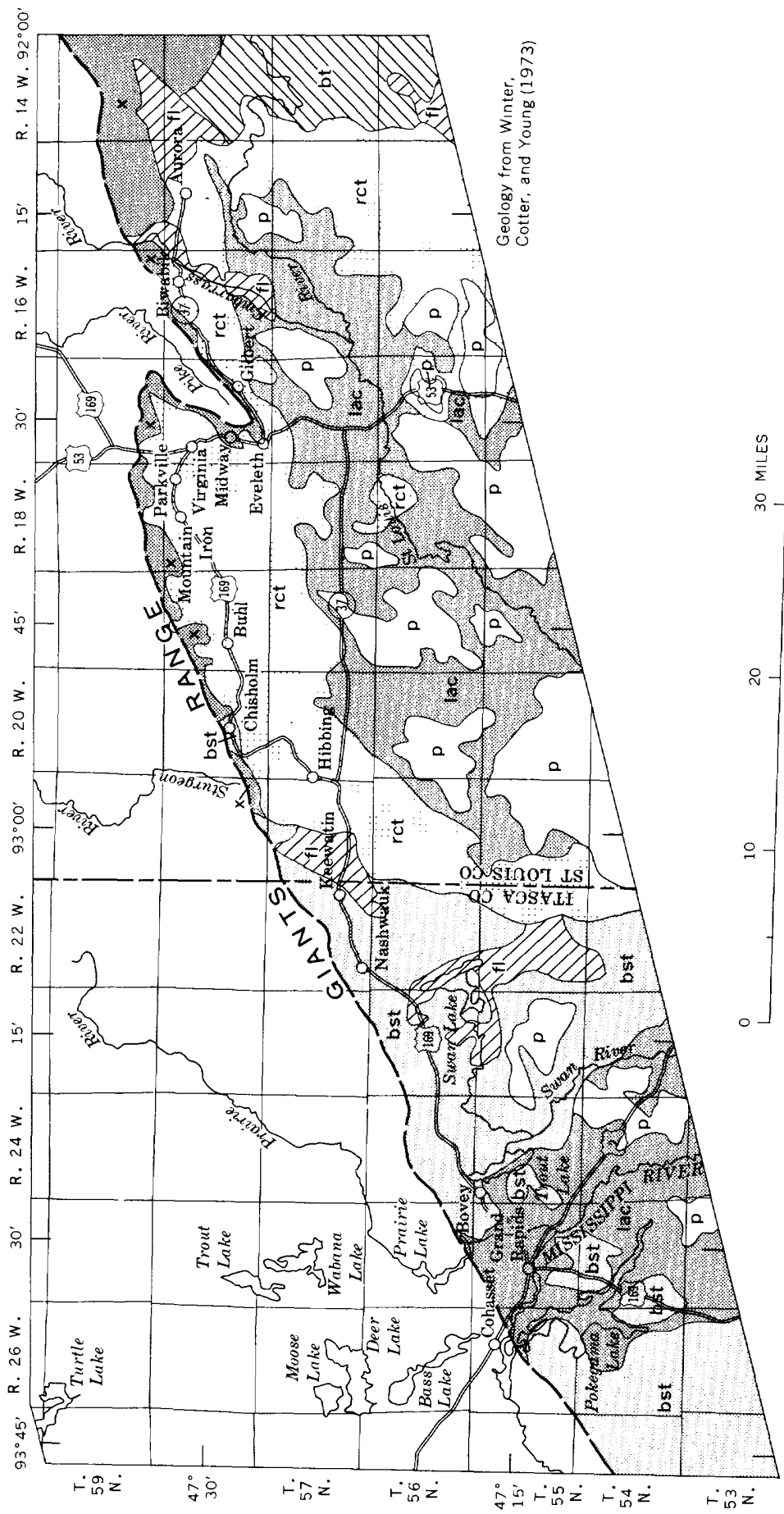



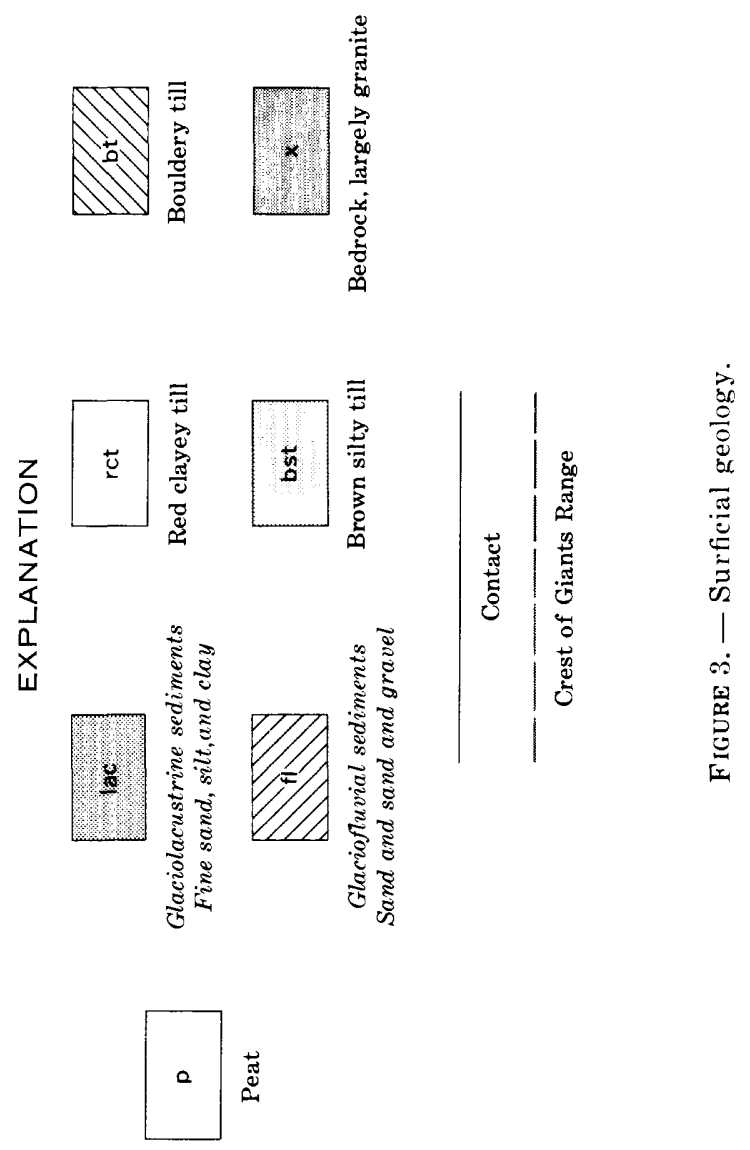
GLACIOFLUVIAL SEDIMENTS BETWEEN BOULDERY AND SURFICIAL TILLS

The glaciofluvial deposits between the bouldery and surficial tills are the thickest and most continuous of the stratified drift units (pl. $3 A$ ). Thickness of these sediments is commonly greater than 50 feet. In a nearly continuous, very irregular area in the general vicinity of the Biwabik bedrock valley and in many other scattered areas across the Iron Range, the thickness exceeds 100 feet.

The horizontal variation in grain size is great in this stratigraphic unit, which can be inferred by comparing maps $A$ and $B$ on plate 3. That much of the stratified drift in this unit is relatively fine grained can be inferred from the difference between the large area composed of thick sediments, represented by widely spaced contours on plate $3 A$, and the smaller area composed of highly transmissive, coarse-grained sediments represented by the narrowly spaced contours on plate $3 B$.

The thicker, coarse-grained bodies of stratified drift head in, or "point" toward, notches in the Giants Range. These fluvial sediments were deposited at this stratigraphic interval when the Rainy ice lobe retreated north of the Giants Range, and sedimentladen meltwaters poured southward through the notches (Winter, 1971). Awareness of this relation between bed composition and configuration and origin can be used in ground-water exploration because coarse-grained sand and gravel bodies are probably yet to be discovered south of the larger notches.

\section{SURFICIAL TILL}

The surficial till in the Mesabi Range area is thin, generally less than 25 feet thick, but continuous; relatively few test holes did not penetrate the surficial till. In only a few areas of about several square miles is this till unit greater than 25 feet thick. Immediately west of Hibbing and 2-8 miles west of Eveleth, the till is greater than 50 feet thick.

The surficial till (fig. 3) consists of two subunits distinguished largely by color and to a lesser degree, by grain size of the matrix. In the western part of the area, the surficial till is brown and silty and is characterized by a light- to medium-brown sandy, silty, and calcareous matrix. In the eastern part of the area, the till is red and clayey and is characterized by a red to reddish-brown clayey, silty, and calcareous matrix.

SURFICIAL GLACIOFLUVIAL SEDIMENTS

Glaciofluvial (including glaciolacustrine) sediments cover much of the land surface in the Mesabi Iron Range area. Most of the sediments are associated with glacial lakes Aitkin II and Upham II (see Winter, 1971). This stratified drift is generally less 
than 25 feet thick. The only large body of surficial glaciofluvial sediments occurs in the area of the Biwabik bedrock valley. This deposit covers many square miles and reaches a thickness of more than 100 feet (fig. 4).

Much of the glaciofluvial sediment overlying the red clayey till in the area of the Biwabik bedrock valley is fine grained. Even where the sediment is coarsest and the deposit is relatively thick, the transmissivity values shown in figure 5 are considerably lower than those for much of the glaciofluvial sediment between the surficial till and bouldery till (pl. $3 B$ ).

\section{GROUND-WATER MOVEMENT}

Ground water in the Iron Range area occurs within the geologic framework previously described. The water that enters the ground-water system is that which percolates through the soil zone and the unsaturated zone. Once the water reaches the zone of the earth's crust that is saturated with water, its course of movement is controlled by the fluid potential of ground water. This potential is dependent to a large degree on the hydraulic conductivity of the geologic materials and on the configuration of the water table.

A contour map of the water table, which is the upper surface of the zone of saturation, can be used to show the direction of water movement within the ground-water system. Under natural conditions the water table usually is a subdued image of the land surface; it is high under hills and low under depressions. Such a profile indicates that recharge occurs in local topographically high areas, and that discharge occurs in the adjacent lowlands, usually occupied by streams, lakes, or wetlands. In this report no watertable map was constructed because of such a correlation between water movement and topography. Instead, a generalized topographic map (fig. 2) is used to show the general direction of ground-water movement. At any place in the Mesabi Range area, the water table is probably not more than 25 feet below land surface, and in most of the area it is within 10 feet of the land surface. These conditions do not exist within a mile or two of active mines, where dewatering causes unsteady ground-water flow conditions.

Most of the water that enters the ground-water system does not move deeply into the system but discharges to adjacent lowlands. Of the water that does move deeper into a more regional ground-water flow system, most eventually discharges to a major stream or wetland outside of the local area. A relatively minor amount of water that percolates through the drift moves into the bedrock formations. 


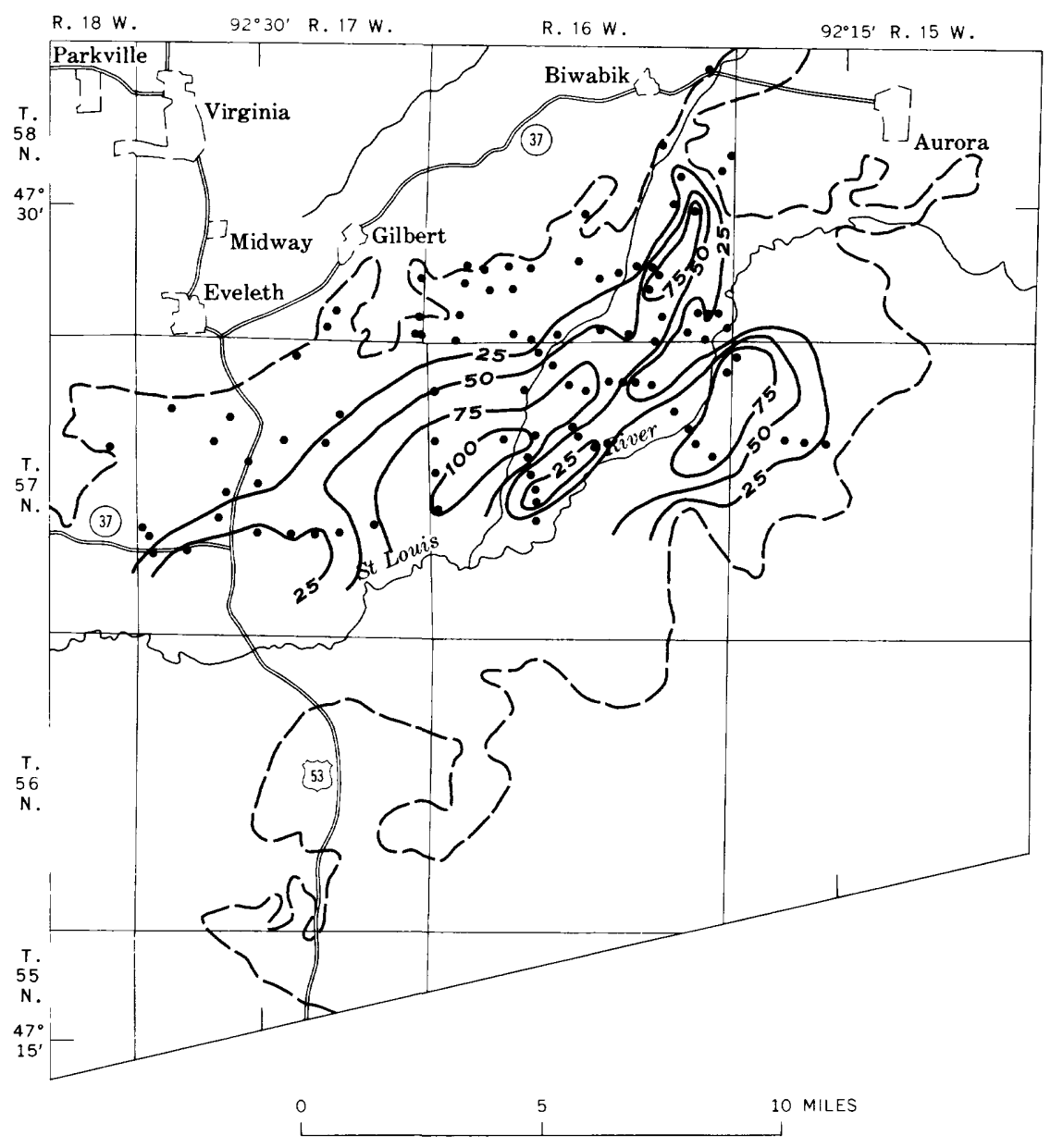

\section{EXPLANATION}

Test hole

Extent of surficial glaciofluvial sediments

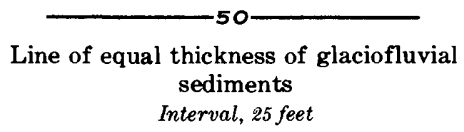

Figure 4. - Thickness of surficial glaciofluvial sediments. 


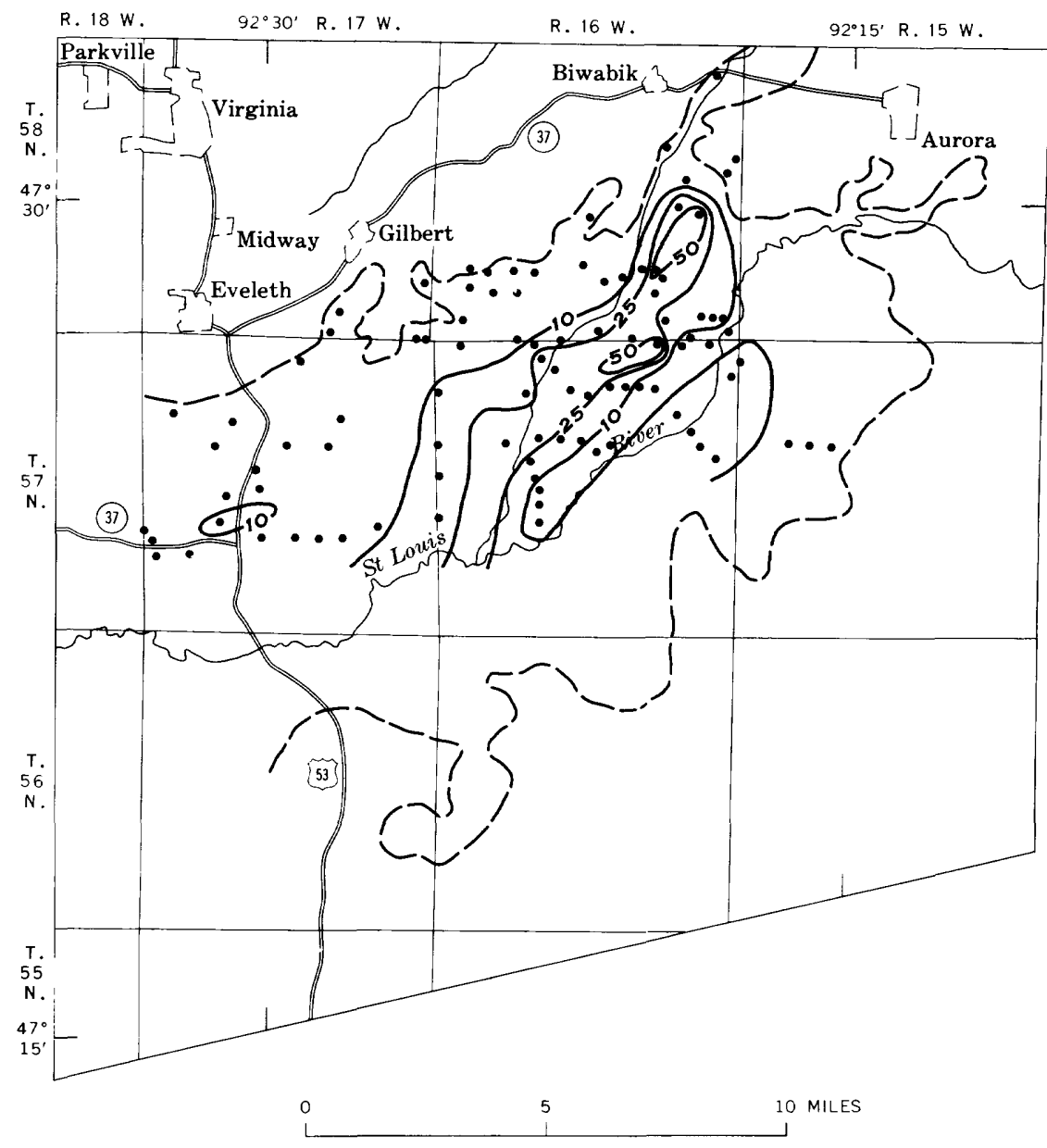

EXPLANATION

Test hole

Extent of surficial glaciofluvial sediments

Line of equal transmissivity of glaciofluvial sediments

Interval, in thousands of gallons per day per foot, is variable

Figure 5. - Transmissivity of surficial glaciofluvial sediments. 
The direction of water movement within the bedrock is largely unknown. Most recharge to the bedrock probably occurs in the open-pit mines, many of which are filled with water. South of the area of mining some water moves into the bedrock from the drift. However, at some localities water in the bedrock moves upward and is discharging to the drift. A test hole drilled by the Minnesota Geological Survey south of Buhl encountered water under high hydrostatic pressure in a fractured zone of the Virginia Slate (G. B. Morey, oral commun., 1971). This indicates that the interchange of water between the drift and the bedrock, although probably not large in quantity, is complex and needs further study for adequate definition.

\section{GROUND WATER AVAILABLE FOR DEVELOPMENT}

To plan and manage the water resource effectively, the total quantity of water that can be developed on a sustained basis must first be estimated. Only after a thorough understanding of the availability of surface and ground water in time and space is achieved can the optimum conjunctive use of both sources of water be realized. Surface water has been discussed for the area by Barr Engineering (1969), Minnesota Department of Conservation (1964), and Oakes and Bidwell (1968). The approximate quantity of ground water that can be developed on a sustained basis is assumed to be some quantity less than the amount that annually recharges the ground-water system. Development of more than this amount results in water being pumped from storage. If more water is pumped from storage than is replenished, dewatering of the aquifer beyond an optimum limit may result.

\section{ESTIMATE OF GROUND-WATER RECHARGE}

Recharge to the ground-water system can be estimated by determining ground-water discharge, assuming the ground-water system is in dynamic equilibrium. Ground-water discharge consists largely of ground-water runoff (stream base flow) and groundwater evapotranspiration. Underflow must also be estimated because an excess of either inflow or outflow can have a significant effect on the quantity of water estimated to be available for development.

Base flow of streams for 38 drainage basins in Minnesota was determined by Ackroyd, Walton, and Hills (1967) using techniques of stream-hydrograph separation outlined by Linsley, Kohler, and Paulhus (1958). Four of the basins are immediately north of the area of this report and have physiographic settings similar to that of this area. Annual ground-water runoff was determined for years of near-, below-, and above-normal precipi-

\footnotetext{
${ }^{1}$ Virginia Argillite of present Geological Survey usage.
} 
tation. Average ground-water runoff for these four basins was about 6 inches, and the difference between years of near- and below-normal precipitation was small.

Cotter, Young, Petri, and Prior (1965a), in a study of 5,000 square miles that includes the Mesabi Iron Range, estimated mean annual ground-water runoff to be 2.5 inches. In view of the value of 6 inches obtained by Ackroyd, Walton, and Hills (1967) and the lower value obtained by Cotter, Young, Petri, and Prior (1965a), an estimate of ground-water runoff of 4 inches in the study area seems reasonable.

Because the water table in the study area is near the land surface at many places, part of the ground water evaporates and part is transpired by plants. Although the quantity of ground water lost to evapotranspiration is unknown and may amount to several inches, the average quantity that might be diverted to pumping is estimated to be 1 inch annually.

As a cross-check on the above method, ground-water hydrographs were used to estimate ground-water recharge. On the basis of water-level fluctuations in several observation wells and an assumed specific yield of 0.25 , estimated ground-water recharge is about 5 inches annually.

Ground-water inflow, which must also be considered in estimating available ground water, is assumed to be negligible. Groundwater underflow into the area is small because the Giants Range is a very effective barrier boundary. The two streams, Embarrass and Prairie Rivers, that enter the area from the north flow through narrow notches in the granite, so ground-water underflow at these places is minimal. A small amount of underflow probably enters the area from the east along the St. Louis River valley, and a larger amount probably enters from the west along the Mississippi River valley.

Ground-water outflow is also negligible because the streams, where most underflow would be concentrated, leave the area through glacial-lake basins. In these basins the surficial deposits are fine grained, the streams have poorly defined valleys, and hydraulic gradients within the ground-water system are low.

Because the effects of inflow and outflow are negligible, the estimated annual ground-water recharge remains at 5 inches. This quantity of water over the entire 1,400-square-mile report area is equivalent to about $330 \mathrm{mgd}$ (million gallons per day). In order to develop any of this total, aquifers must exist that will yield large quantities of water to individual wells. Economic and social considerations, such as distance of aquifer from point of use, will reduce the amount of ground water that may be withdrawn on a practical basis, so the total recovery will be much less than 330 mgd. 


\section{AREAL DISTRIBUTION OF AQUIFERS}

The relative water-yielding capabilities of the various parts of the glaciofluvial sediments are shown on plates $2 B$ and $3 B$ and in figure 5. Transmissivity, $T$, a hydraulic property of aquifers, is the rate at which water of the prevailing kinematic viscosity is transmitted through a unit width of the aquifer under a unit hydraulic gradient. The higher the transmissivity of an aquifer, the more easily water moves through it, which should result in higher yields to wells. Chances of completing high-yield wells are much better in areas where $T$ values are 100,000 gpd per ft (gallons per day per foot) than where the values are less than 25,000 gpd per ft. Transmissivity values are highest where the aquifer is thick or coarse grained, or both. In the areas where transmissivity is highest, yields as much as 1,000 gallons per minute to individual wells can probably be obtained.

The transmissivity maps were constructed on the basis of sample and log inspection, as discussed previously. Generally, transmissivity is determined by test pumping wells in the aquifer and analyzing the water-level changes in adjacent observation wells. A number of such tests were made in the 1950's in different parts of the area, mostly to evaluate the hydraulic characteristics of the glaciofluvial sediments between the surficial and bouldery tills. Transmissivity values calculated from pumping-test data agreed fairly well with values shown on plate $3 B$.

The transmissivity data, as shown on plates $2 B$ and $3 B$ and in figure 5, suggest that the glaciofluvial sediments between the bouldery and surficial tills ( $\mathrm{pl}$. $3 B$ ) have the greatest potential for large-scale ground-water development. The data also suggest that, regardless of the stratigraphic interval, the best potential aquifers generally occur in the same areas, overlying each other (fig. 6). Thus, since all local ground-water recharge must be from percolation of rainfall, any given aquifer shares the total recharge with other overlying or underlying aquifers. The following discussion, therefore, centers on the principal aquifer, the glaciofluvial sediments between the bouldery and surficial tills.

About half of the study area contains all the test holes and therefore is considered "proven"; the rest of the area is "unproven." The principal aquifer has transmissivities greater than $50,000 \mathrm{gpd}$ per $\mathrm{ft}$ in approximately 140 square miles of the proven area. Assuming recharge is 5 inches annually, about $33 \mathrm{mgd}$ could be developed in the proven area. As development progresses, the influence of pumping will spread beyond the areas of 50,000gpd-per-ft transmissivity, and the increase in area of recharge could increase the amount of ground water that may be withdrawn to about $40 \mathrm{mgd}$. 
Assuming that the unproven area has the same percentage of aquifers with greater than 50,000 gpd per ft transmissivity as the proven area (20 percent), an additional $40 \mathrm{mgd}$ might be available in the unproven area. It should be realized also that all the areas of high potential for ground-water development are not delineated in this report. Others, especially those more local in extent, may remain undiscovered even in the proven area.

In summary, the quantity of ground water available on a continuing basis (the practical sustained yield) is estimated to be as much as $40 \mathrm{mgd}$ in the area where transmissivity is greater than 50,000 gpd per $\mathrm{ft}$ and could be as much as $80 \mathrm{mgd}$ in the entire report area. Although this estimate is very general, it is as close as the data and analytical methods available for this project permit. Refinement of this estimate would be possible through analog or digital modeling of the ground-water system, although the modeling would require data from the unproven area. Also, through modeling it would be possible to experiment with development plans.

\section{MANAGEMENT CONSIDERATIONS}

Large-scale development of ground water should not have a marked effect on streams that transect the study area, except perhaps locally. Of the areas that have high potential for groundwater development, only two are transected by relatively large streams: the area on the western end of the Iron Range near Grand Rapids and on the eastern end in the vicinity of the Biwabik bedrock valley.

In the area near Grand Rapids the Mississippi River and Pokegama Lake are potential sources of recharge. Development of ground water in these areas could then exceed the 5-inch annual recharge limit.

Ground-water development in the vicinity of the Biwabik bedrock valley should not affect the Embarrass and the St. Louis Rivers. Although the aquifer beneath the surficial till underlies short reaches of these rivers, the effect would probably be small because a large part of the base flow in these reaches probably comes from the surface sand-and-gravel deposits.

A second management consideration is that local recharge probably can be increased by several inches in areas of groundwater development. The principal aquifer is overlain nearly everywhere by surficial till of low permeability. By completely removing this relatively thin geologic unit in areas of intensive development, ground-water recharge can be increased. In addition, surface spreading techniques of artificial recharge might then be feasible in such areas, which would further increase recharge. 


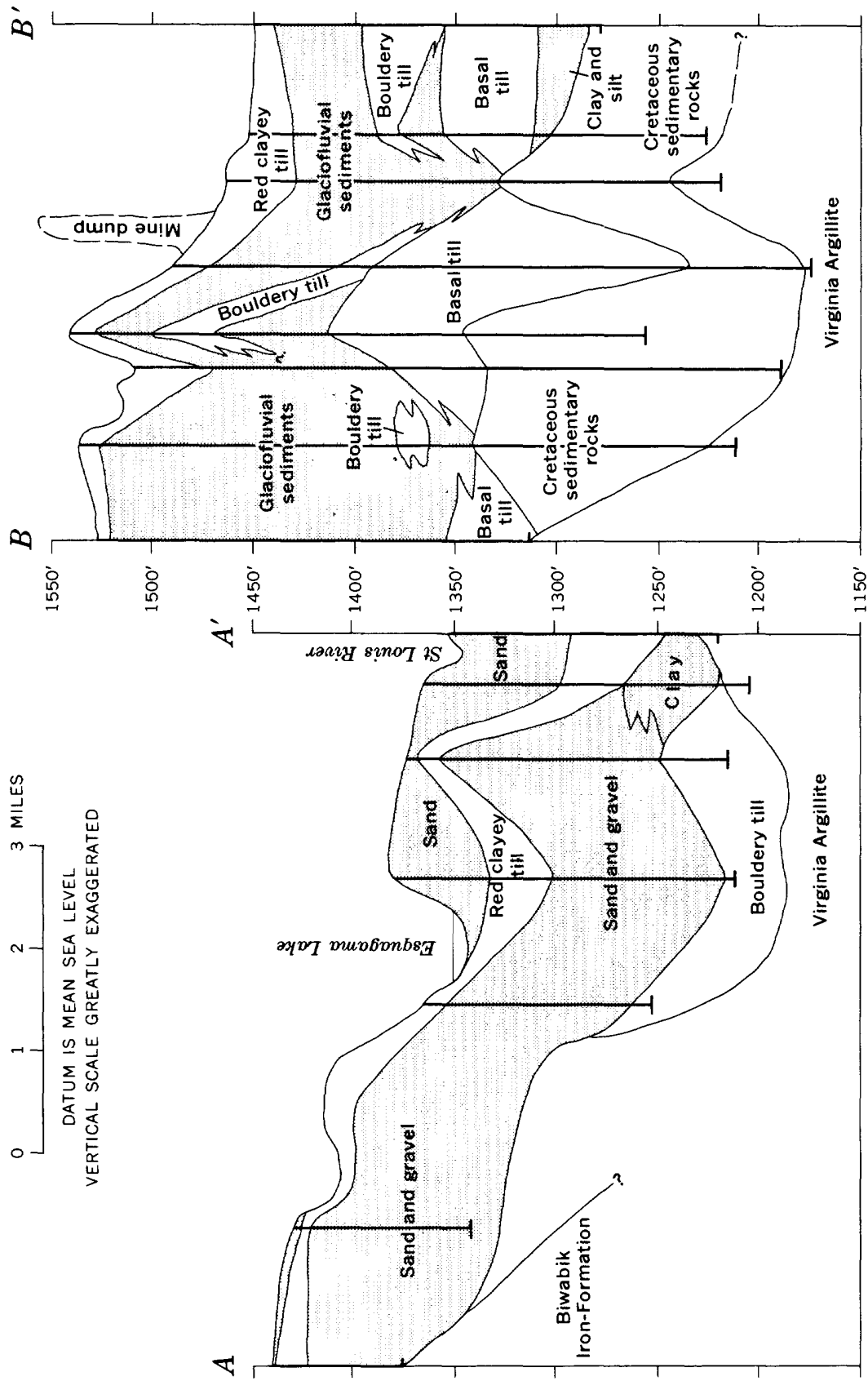



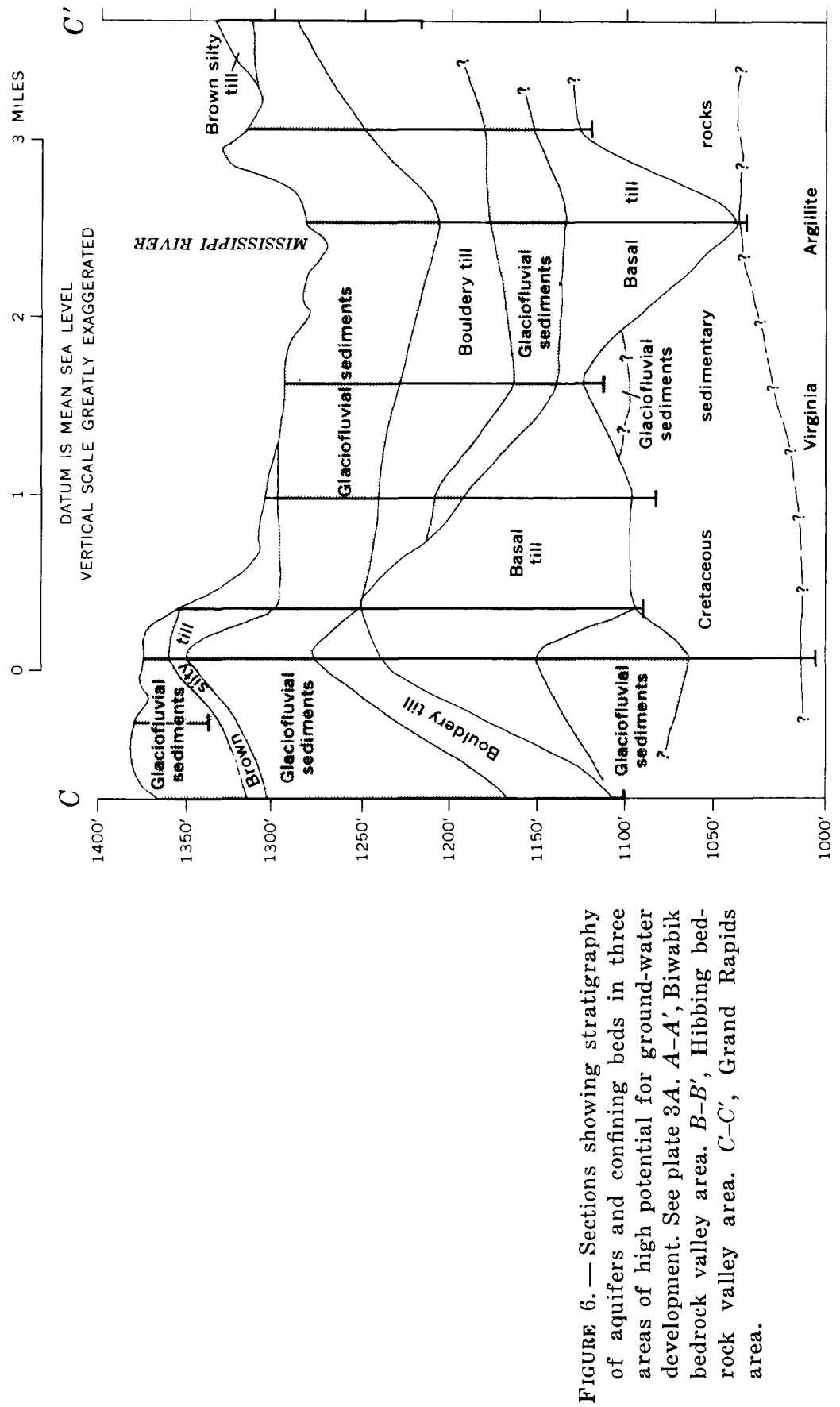
A third management consideration, perhaps the most important, is that optimum pumping programs and well spacing must be considered because of the high cost of pipelines. Considering the size and distribution of the highly transmissive parts of the aquifer shown on plate $3 B$, unless a water demand can be satisfied locally, pipeline costs may make ground-water development unfeasible. Pipeline costs, again, would make uniform spacing of wells over the entire aquifer economically unfeasible. Therefore, development probably will be as pumping centers in areas of maximum demand. Initial development probably will occur where the aquifer is present near municipalities and iron-ore processing plants. In more remote areas development would occur only if a future demand was established locally. It is therefore unlikely that the quantity of ground water estimated to be available will be developed.

A fourth consideration is that this report considers only a part of the total ground-water resource-the glacial drift. It would be desirable to analyze potential ground-water development from the bedrock units which would increase the total ground water available for development by an unknown amount.

\section{CONCLUSIONS}

1. Aquifers many square miles in extent exist within the drift in the Mesabi Iron Range area. The stratigraphic position of the principal aquifer is between the surficial and bouldery tills.

2. The aquifers in the area are capable of yielding as much as 1,000 gallons per minute to individual wells in the better locations within the aquifers.

3. The projected water demand of the Iron Range area of $168 \mathrm{mgd}$ in 1980 to $318 \mathrm{mgd}$ in 2020 (Barr Engineering, 1969) can be partly met by ground water. The estimated practical sustained yield of the ground-water resource from glacial drift is between 40 and $80 \mathrm{mgd}$.

\section{REFERENCES}

Ackroyd, E. A., Walton, W. C., and Hills, D. L., 1967, Ground-water contribution to streamflow and its relation to basin characteristics in Minnesota: Minnesota Geol. Survey Rept. Inv., RI-6, 36 p.

Barr Engineering Co., 1969, Development of water resources in the Lake Superior watershed of Minnesota: Minneapolis, Barr Engineering Co., $47 \mathrm{p}$.

Cotter, R. D., Young, H. L., Petri, L. R., and Prior, C. H., 1965a, Ground and surface water in the Mesabi and Vermilion Iron Range area, northeastern Minnesota: U.S. Geol. Survey Water-Supply Paper 1759-A, 36 p. $1965 \mathrm{~b}$, Water resources in the vicinity of municipalities on the western Mesabi Iron Range, northeastern Minnesota: U.S. Geol. Survey Water-Supply Paper 1759-B, 24 p. 
$1965 c$, Water resources in the vicinity of municipalities on the westcentral Mesabi Iron Range, northeastern Minnesota: U.S. Geol. Survey Water-Supply Paper 1759-C, 21 p.

$1965 \mathrm{~d}$, Water resources in the vicinity of municipalities on the central Mesabi Iron Range, northeastern Minnesota: U.S. Geol. Survey Water-Supply Paper 1759-D, 20 p.

$1965 \mathrm{e}$, Water resources in the vicinity of municipalities on the eastcentral Mesabi Iron Range, northeastern Minnesota: U.S. Geol. Survey Water-Supply Paper 1759-E, 23 p.

$1965 \mathrm{f}$, Water resources in the vicinity of municipalities on the eastern Mesabi Iron Range and the Vermilion Iron Range, northeastern Minnesota: U.S. Geol. Survey Water-Supply Paper 1759-F, 27 p.

Cotter, R. D., Young, H. L., and Winter, T. C., 1964, Preliminary surficial geologic map of the Mesabi-Vermilion Iron Range area, northeastern Minnesota: U.S. Geol. Survey Misc. Geol. Inv. Map I-403.

Lindholm, G. F., 1968, Geology and water resources of the Hibbing area, northeastern Minnesota: U.S. Geol. Survey Hydrol. Inv. Atlas HA-280.

1970 , An appraisal of ground water for irrigation in the Wadena area, central Minnesota: U.S. Geol. Survey Water-Supply Paper 1983, 56 p. [1971].

Linsley, R. K., Jr., Kohler, M. A., and Paulhus, J. L. H., 1958, Hydrology for Engineers: New York, McGraw-Hill Book Co., 340 p.

Lohman, S. W., and others, 1972, Definitions of selected ground-water termsRevisions and conceptual refinements: U.S. Geol. Survey Water-Supply Paper 1988, 21 p.

Maclay, R. W., 1966, Reconnaissance of the geology and ground-water resources in the Aurora area, St. Louis County, Minnesota: U.S. Geol. Survey Water-Supply Paper 1809-U, 20 p.

Minnesota Department of Conservation, 1964, The St. Louis River watershed unit: Minnesota Div. Waters Bull. 22, 54 p.

Minnesota Geological Survey, 1970, Geologic map of Minnesota: Hibbing Sheet: Minneapolis, Minn. Geol. Survey.

Oakes, E. L., 1970, Geology and ground-water resources of the Grand Rapids area, north-central Minnesota: U.S. Geol. Survey Hydrol. Inv. Atlas $\mathrm{HA}-322$.

Oakes, E. L., and Bidwell, L. E., 1968, Water resources of the Mississippi Headwaters Watershed, north-central Minnesota: U.S. Geol. Survey Hydrol. Inv. Atlas HA-278.

Reeder, H. O., 1972, Availability of ground water for irrigation from glacial outwash in the Perham area, Otter Tail County, Minnesota: U.S. Geol. Survey Water-Supply Paper 2003.

State Planning Agency, 1970, Minnesota water and related land resourcesfirst assessment: St. Paul, State Planning Agency, 396 p.

Van Voast, W. A., 1971, Ground water for irrigation in the Brooten-Belgrade area, west-central Minnesota: U.S. Geol. Survey Water-Supply Paper 1899-E, 24 p.

Winter, T. C., 1971, Sequence of glaciation in the Mesabi-Vermilion Iron Range area, northeastern Minnesota, in Geological Survey Research 1971: U.S. Geol. Survey Prof. Paper 750-C, p. C82-C88.

Winter, T. C., Cotter, R. D., and Young, H. L., 1973, Petrography and stratigraphy of glacial drift, Mesabi-Vermilion Iron Range area, northeastern Minnesota: U.S. Geol. Survey Bull. 1331-C. 

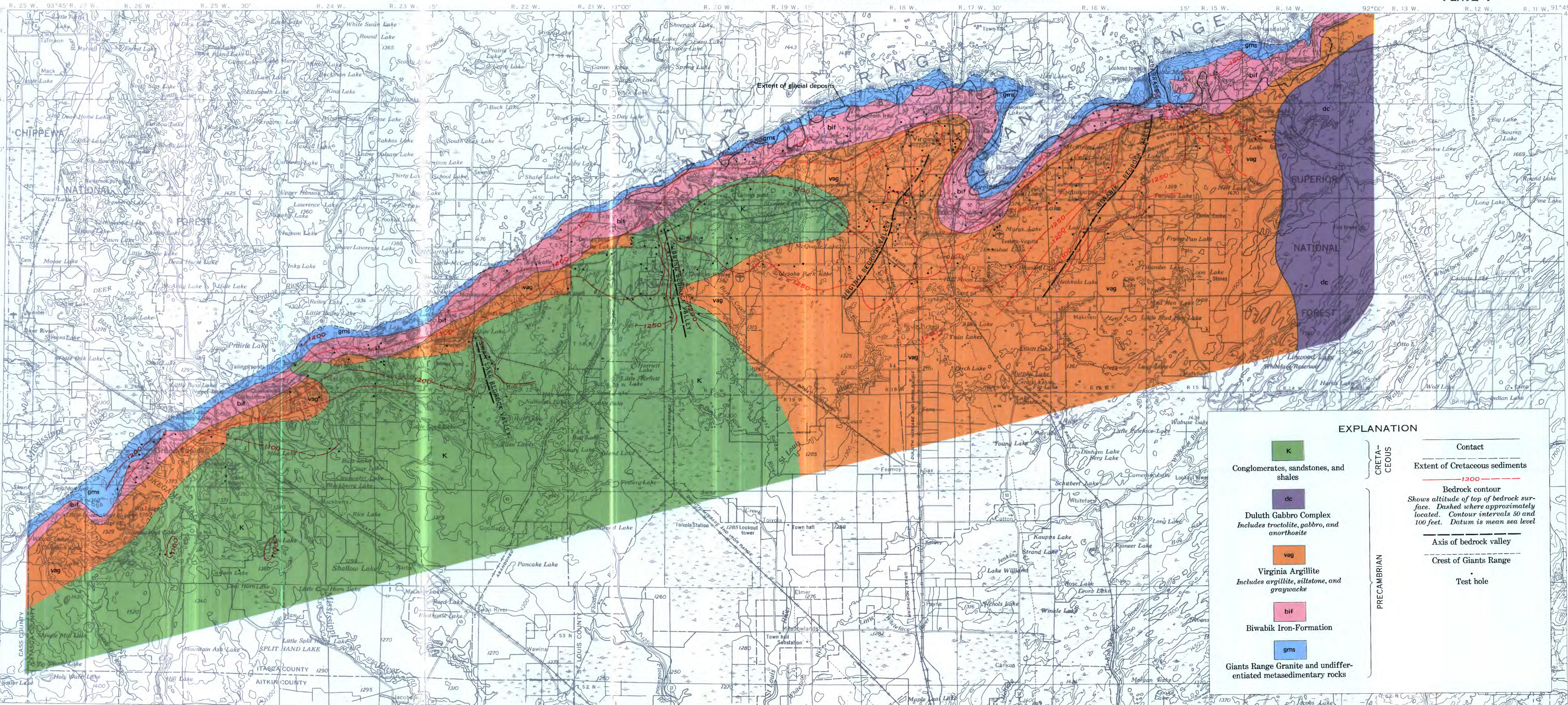

A. BEDROCK GEOLOGY AND CONFIGURATION OF BEDROCK SURFACE
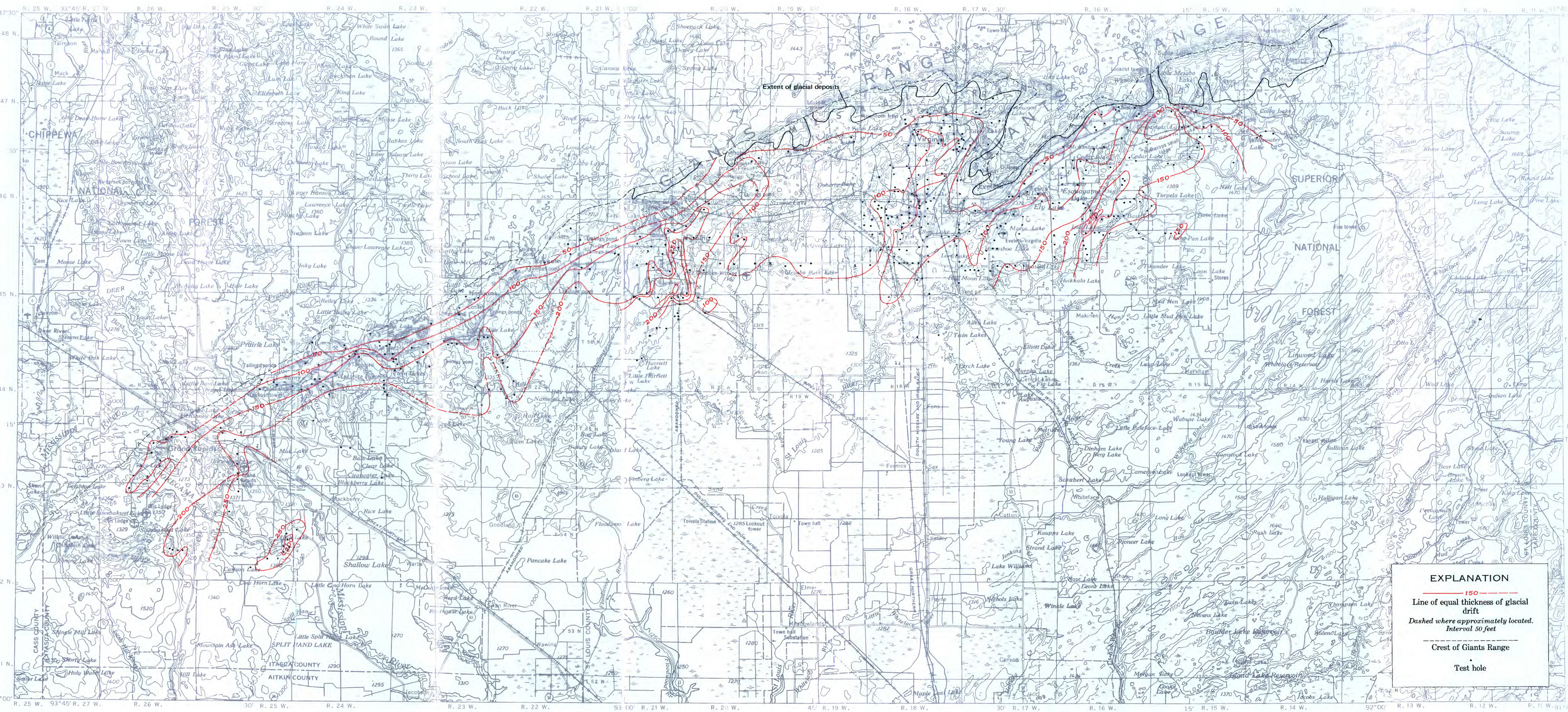

B. THICKNESS OF GLACIAL DRIFT 


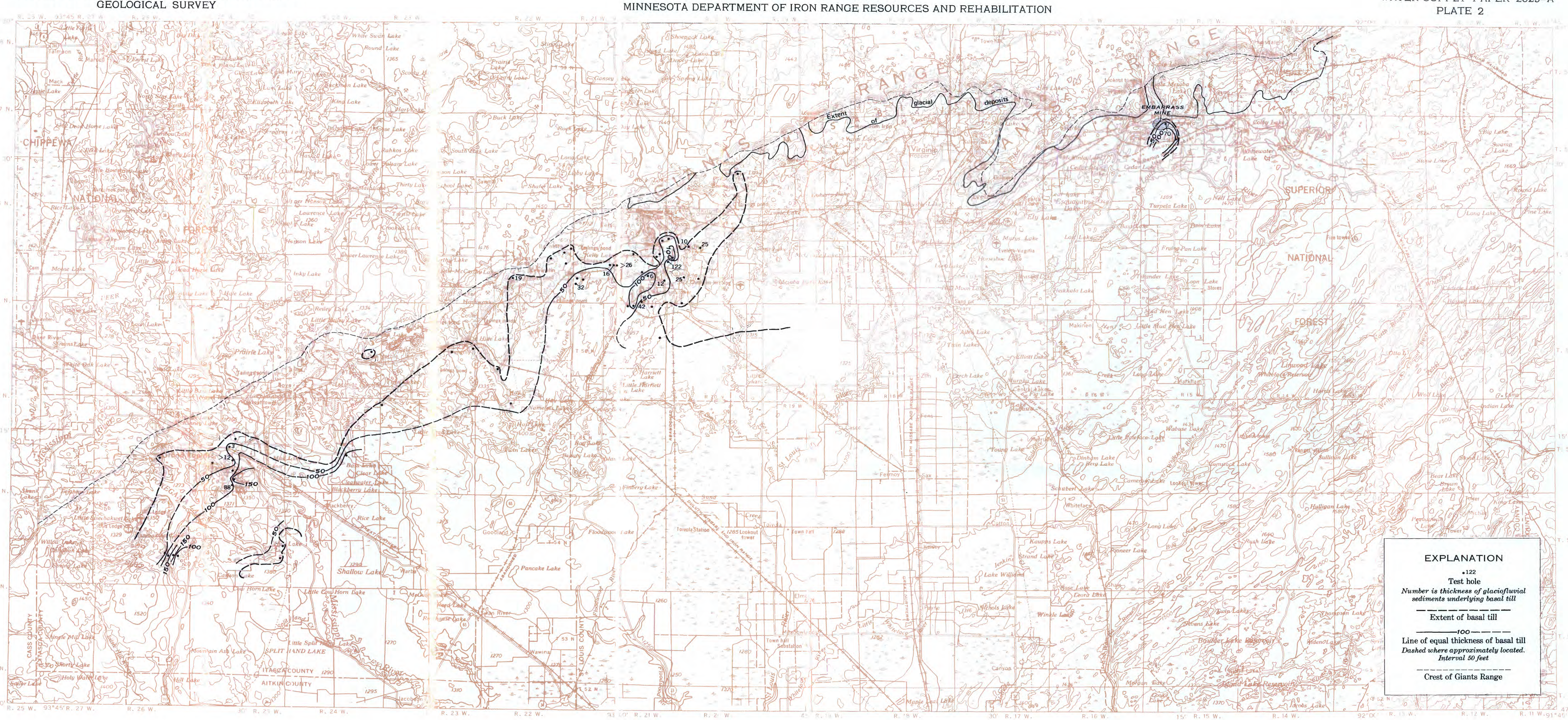

A. EXTENT AND THICKNESS OF BASAL TILL

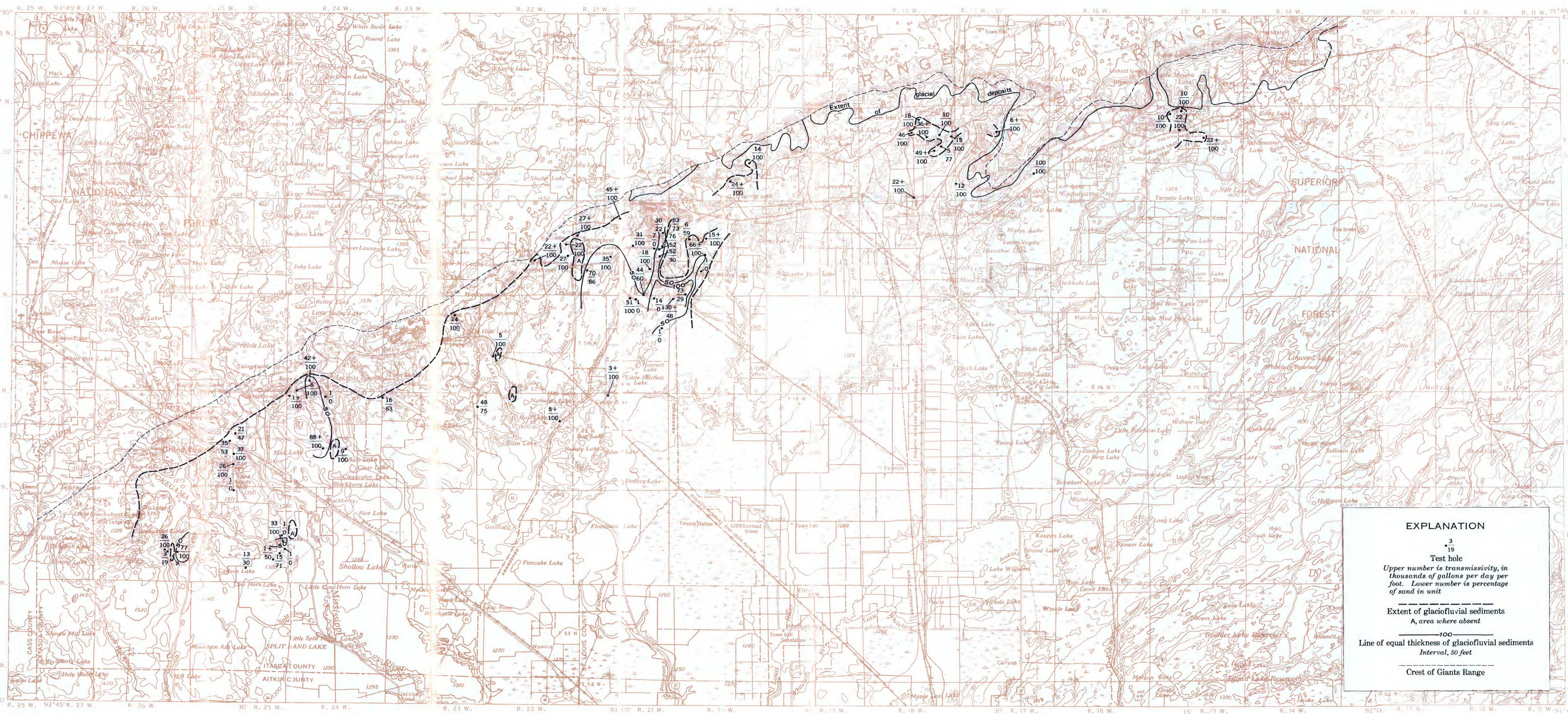




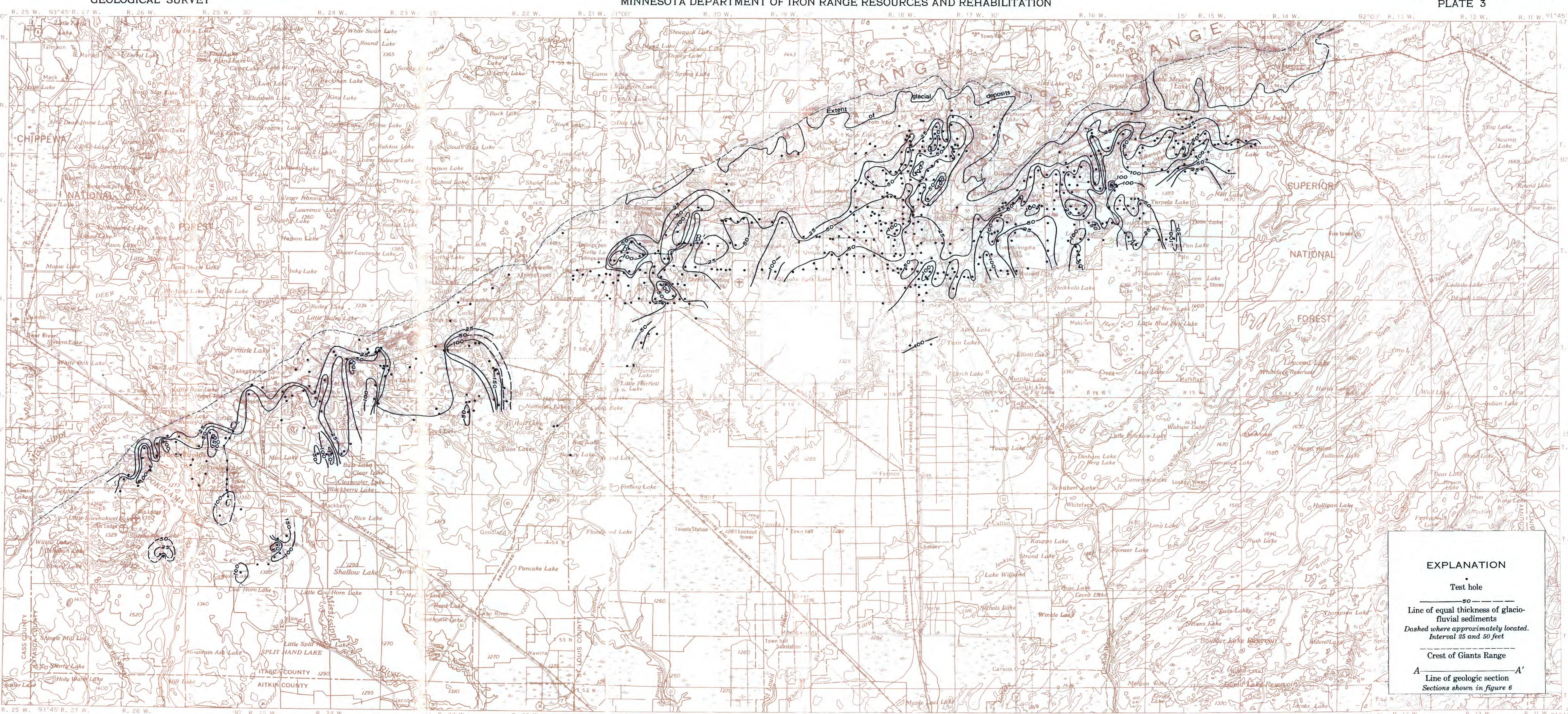

A. THICKNESS
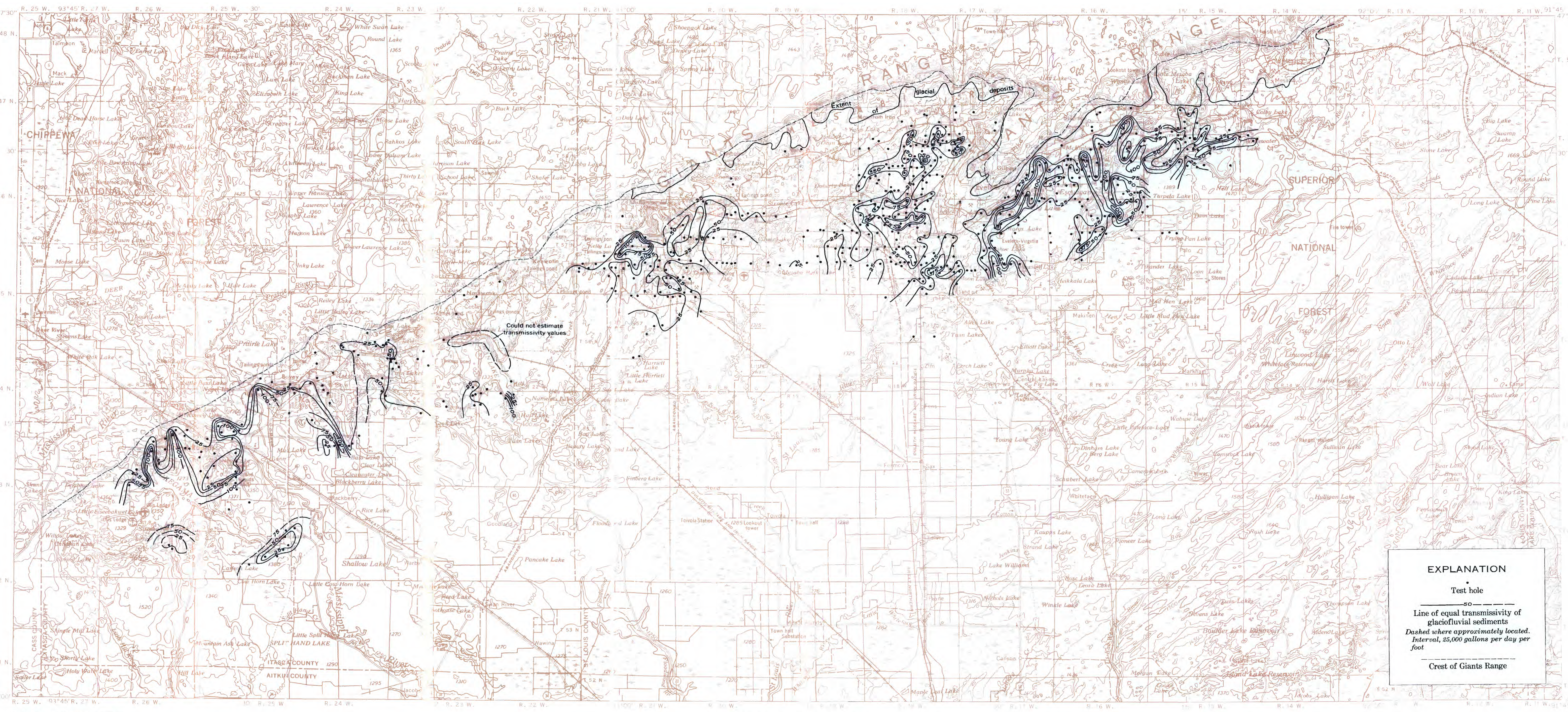

B. TRANSMISSIVITY 